\title{
EMINENT DOMAIN IN CONTINENTAL EUROPE
}

\author{
By William D. McNulty, of the New York Bar.
}

No country which we style civilized can boast of a law distinctively its own, for all have borrowed, and all have profited by the experiences of other nations. This is particularly the case in Continental Europe, where the laws are based on the Roman law, modified to suit the political, social and economic requirements of each state. And, too, we find that the foundation of Roman law, the Twelve Tables, was a compilation of the customary law of Rome, hitherto administered by the Patricians. The Code and Digest of Justinian, to which the modern world owes so much, was a revision of the whole Civil Law, adjusted to the needs of the people, and the Code Napoleon was based on the Roman Law, as modified and observed in France, as well as on the Code of Louis XIV, compiled a hundred years earlier.

In tracing the development of the right of Eminent Domain, in continental law we find only indefinite and unsatisfactory allusions to the existence of such a principle, until the early part of the eighteenth century, when we are told that France, on the 26th of May, I705, adopted a rule of compensation to provide indemnity where houses, timber lands, and vineyards were taken by the State; the damages to equal the value of the property, less its computed value as arable land.

The story of Naboth's vineyard has been seriously cited by Merlin and other writers, as the earliest known instance of expropriation, but, as a matter of fact, it does not come within the right of Eminent Domain, for Naboth, claiming that he could not give up his father's inheritance, refused to sell his land to King Ahab, whose agents afterwards killed Naboth, in order that their master might seize the vineyard he coveted; it was not even a "forced sale," as the king got possession through murder and fraud and not by way of a compensation, so that the transaction, if such it can be called, was all on the part of the king and his agents and cannot fairly be classed under the law of Eminent Domain.

EARLY MANIFESTATION OF THE RIGHT.

The use of such a right as Eminent Domain could not be expected in the earlier stages of civilization, for its necessity only 
arose with the desire for public works, and where the respect for private property has become well established. The right does not appear to have been clear and certain in Greek or early Roman law, and it is more than probable that the privilege of the State to take private land would have been considered an infringement of the rights of citizens, as these were understood in Rome. With the growth of public works, however, the enlargement of cities, and the making of straight roads and highways, private property must have been utilized, and some rule of compensation must have been recognized in these later times by those nations which enjoyed a high civilization.

Turning first to Greece we read in the Athenian Constitution of Aristotle (discovered in I89I) that in the adjustment of a dispute between the cities of Athens and Eleusis, among the agreements of settlement was one providing for the transfer of property in Eleusis to the Athenians, on terms that imply the use of an existing rule for the valuation of private property by representatives of the city:-

"If any of the seceding party (i.e. Athenians) should wish to take a house in Eleusis, the people would help them to obtain the consent of the owner; but if they could not come to terms they should appoint three valuers on either side, and the owner should receive whatever price they should appoint."

With the Romans we learn that confiscation was an act of political power, and, in cases where private property was seized in virtue of this power, and any compensation, direct or indirect, was made to the owner, the transaction was recognized in the law as a "forced sale."

Where an aqueduct was constructed on private land, the exemption of all charges to the owner of that land, was an indirect indemnity for its use by the State, and where the city walls stood - on private property, the owner thereof was granted the free use of the towers, but with the obligation of keeping them in proper repair. Respect for the rights of the individual citizen was paramount with the Romans. We must infer, then, that the consent of the proprietors in these cases had been first obtained.

As the power of expropriation was reserved to the highest authorities, there were occasions when even they could not execute their plans successfully. For instance, when the censors, in the year I79 B. C., had devised the project of supplying the city with water by means of an aqueduct, their purpose was defeated by the refusal of a proprietor to allow it to be carried through 
his lands. At a later period the senate decreed that it should be lawful to take from adjoining lands of individuals the materials requisite for the repairs of aqueducts, upon an estimate of the value, or damages, to be made by good men, and doing at the same time, the least possible injury to the owners.

In the Amals of Tacitus, Bk. I, P. 75, we are told that, when a private house was injured by a public road or aqueduct, the Emperor Tiberius paid the damage on petition by the party to the senate. This instance, however, although striking, does not prove that the principle was generally recognized, or established, and when, in the year 398 A. D., an order from the emperor was issued to the prefect of the city to clear the ramparts and public buildings of certain obstructions which cause fire, or obstruct pub. lic places and entrances to public buildings, no mention is made of indemnity. (See Code of Justinian, Book VIII, Title XII, Sec. I4). It is possible, however, that the objectionable structures were unauthorized, or had been previously condemned.

The "forced sale" of the Roman law also applied to slaves who were abused to excess by their masters, and the liberty of a slave was sometimes purchased with the public funds as a reward for a service to the State, or an act that was deemed sufficiently praiseworthy for such recognition.

This, however, with the supervision of the sale of meat, grain, and other provisions, and the regulation of various trades, which shows only the exercise of police power, does not come within the limit of the right of Eminent Domain, which is generally understood in Continental Europe to-day to be a law that empowers the State to take private property for public use, upon payment of just and previous compensation.

There is also a case mentioned by Paulus in his Pandects which is cited by Montesquieu and many modern writers on the subject, as showing the existence of expropriation in Roman law, although it is hardly to the point: "Lucius Titius bought lands in Germany beyond the Rhine, and paid part of the price. His heir was sued by the vendor for the balance of the purchase price. The vendor was met with a counter demand for the restoration of the price already paid, upon the ground that these lands' had been in part alienated by the prince, (saying that these possessions were partly appropriated by the prince's order, $)^{1}$ and partly assigned to veterans as bounty. The question was put to Paulus whether

1 Dicens has possessiones ex praecepto principali partim distractas. 
this was at the vendor's risk. Paulus answered that causes of eviction happening after the sale did not concern the vendor, and hence that in the case proposed, the vendor was entitled to demand the balance of the price." Bk. XXI, Title II, \$II.

Nothing is said here of an indemnity, and it is probable that, if there had been any, the suit would not have been brought.

Of the same indirect character is the fragment from Javolenus, in the Digest, Bk. VIII, Title II, 14, I. "If a public road is lost through overflow of a river, or becomes impracticable, the nearest land-owner must furnish another."

This is more nearly related to the servitude of necessity than to Eminent Domain, and there is no mention of indemnity.

\section{ITS SPECULATIVE FORMATION.}

The Germanic theory of the Middle Ages was the unlimited sovereignty of the prince (Herrschersouveränetät). From the twelfth century this sense had been given to the Roman texts. "omnia jura habet Princeps in pectore suo," "quod Principi placuit legis habet vigorem,"3 "error Principis facit jus." Philosophical doctrine was complacent, and found herein the distinction between the true monarch and the republican magistrate.

These notions were combatted by the adherents of the Volkssouveränetät. The prevailing idea was that there was a real ownership (in the emperor) in everything, and hence an absolutely free disposal of the rights of private individuals. By degrees. the contrary opinion, already represented Bulgarus, crowded to the front, to the effect that private property was subject to nothing but the sovereignty of the State, which sometimes means a naked "jurisdictio vel protectio," and sometimes a "dominium."

Out of this right of sovereignty was developed the theory of a right of expropriation foreign to the original Germanic legal consciousness, whereby the power of the State, where State objectsrequire it, is competent to extinguish or modify private rights. (Gierke, Althusius, pp. 266-269.)

The term "eminent domain" is paraphrased from the "dominium eminens" of Grotius, which Whewell translates as "eminent dominion," but common usage, in this country at least, has adopted

2 The prince has all rights in his own breast.

3 What pleases the prince has the force of law.

4 The error of the prince makes law. 
"eminent domain" as giving a more correct and more explicit interpretation to the term in its sense as a peculiar right of the State to take the property of private individuals for public use, on payment of compensation.

In his work on "The Rights of War and Peace," Book I, Chap. I, Section 6, Grotius says: "Right, strictly taken, is again twofold, the one, private, established for the advantage of each individual, the other, superior," as involving the claims, which the State has upon individuals, and their property, for the public good. Thus the regal authority is above that of a father and a master, and the sovereign has a greater right over the property of his subjects, where the public good is concerned, than the owners themselves have. And when the exigencies of the State require a supply, every man is more obliged to contribute towards it, than to satisfy his creditors."

In Book II, Chap. XIV, Sec. VII, he says:

"This is also to be noted, that a right, even when it has been acquired by subjects, may be taken away by the King in two modes; either as a penalty, or by force of 'Eminent Dominion.' But to do this by the force of Eminent Dominion, there is required, in the first place, public utility; and next, that, if possible, compensation be made, to him who has lost what was his, at the common expense. And as this holds with regard to other matters, so does it with regard to rights which are acquired by promise or contract."

Again in Book III, Chap. XX, Sec. VII, referring to the obligations of the State and the individual, he says:

"The right of sovereigns to dispose of the effects of individuals, in order to make peace, is often a disputed point, nor can they exercise this right over the property of subjects in any other manner than as sovereigns. The property of subjects is so far under the eminent control of the State, that the State or the sovereign who represents it, can use that property, or destroy it, or alienate it, not only in case of extreme necessity, which sometimes allow individuals the liberty of infringing upon the property of others, but on all occasions, where the public good is concerned, to which the original framers of society intended that private interests should give way. But when that is the case, it is to be observed, the State is bound to repair the losses of individuals, at the public expense, in aid of which the sufferers have contributed their due proportion. Nor will the State, though unable to repair the 
losses for the present, be finally released from the debt, but whenever she possesses the means of repairing the damages, the dormant claim and obligation will be revived."

Pufendorf, in his compendium on natural law, "De Officio Hominis et Civis," Tit. II, Chap. XV, Sec. 4, says on the subject of Eminent Domain:

"The third right is Eminent Domain, which consists in this, that when public necessity demands it, the goods of any subject which are very urgently needed at the time, may be seized and used for public purposes, although they may be more valuable than the allotted share which he is supposed to give for the welfare of the republic. On this account, the excess value should, in so far as possible, be refunded to the citizen in question, either from the public funds, or from a contribution of the other citizens."

During the seventeenth and eighteenth centuries we see from the works of various Continental writers that the law of Eminent Domain was gradually becoming more firmly established, as the administration of public works increased, and the necessity of opening up new highways made it imperative for the State to encroach on certain portions of improved private property.

Domat, in his treatise "Ies Lois Civiles dans leur ordre naturel," published between 1680-97, treats Eminent Domain as a "forced sale." In Book I, Title II, Sec. XIII, he says:

"It often happens that things belonging to private individuals become necessary for some public use; and if, in these cases, they refuse to sell them, they are constrained to do so by the autonomy of justice, for, all things being made for the use of society, before any one thing can pass to the use of private individuals, these can only possess them on this condition-that their private interest will cede to the public interest when necessity demands it. Thus, a private individual is obliged to sell his inheritance, if it becomes necessary for any public work."

He also cites an ordinance of Philip the Fair in 1303 , giving the right of condemnation for church purposes through a forced sale "justo praetio."

5 "Tertium jus est "Dominium Eminens," quod in eo consistit, ut urgente reip. necessitate, bona subditi cujuspiam, quibus praesens tempus maxime opus habet, ad usus publicos arripi et adplicari queant, licet ista longè superent ratam partem, quam is ad sumtus reip. conferre tenebatur. $\mathrm{Ob}$ quam tamen rationem isti civi quod excedit, de publico, aut ex collatione caeterorum civium, quantum ejus fieri potest, refundi debet." 
Montesquieu, in his great work; "L'Esprit des Lois," published in 1748 , treats the subject of the acquiring of private property for the public use, at some length. In Book 26, Chap. XV, he says:

"As men have given up their natural independence to live under political laws, they have given up the natural community of goods to live under civil laws.

"By the first, they acquired liberty; by the second property. We should not decide by the laws of liberty, which, as we have already said, is only the government of the community, what ought to be decided by the laws concerning property. It is a paralogism to say, that the good of the individual should give way to that of the public; this can never take place, except when the government of the community, or, in other words, the liberty of the subject is concerned; this does not effect such cases as relate to private property, because the public good consists in everyone's having his property, which was given him by the civil laws, invariably preserved.

"Cicero maintains, that the Agrarian laws were unjust; because the community was established with no other view than that everyone might be able to preserve his property.

"Let us, therefore, lay down a certain maxim, that whenever the public good happens to be the matter in question, it is not for the advantage of the public to deprive an individual of his property, or even to retrench the least part of it by a law, or a political regulation. In this case we should follow the rigor of the civil law, which is the palladium of property.

"Thus when the public has occasion for the estate of an individual, it ought never to act by the rigor of political law; it is here that the civil law ought to triumph, which, with the eyes of a mother, regards every individual as the whole community.

"If the political magistrate would erect a public edifice, or make a new road, he must indemnify those who are injured by it; the public is in this respect like an individual who treats with an individual. It is fully enough that it can oblige a citizen to sell his inheritance, and that it can strip him of the great privilege, which he holds from the civil law, of not being forced to alienate his possessions."

He quotes Beaumanoir's work on Jurisprudence (Chap. XXII) as showing that, in the twelfth century, the great highways were 
maintained under conditions similar to those of the eighteenth century.

In the twelfth century Montesquieu says this was regulated by the civil law; in the eighteenth by the political law.

Wolff, in his "Jus Naturae," Halae Magd. 1748, par. VIII, Cap. I, Section IIo to II9, says:

"If the public welfare requires that the Ruler of the State should dispose-of the property of citizens in a certain manner, the law should give him power so to dispose of it."

He adds that this power, conceded to the Chief of the State, is called "Dominium Eminens." "Eminent Domain differs from the common domain in that the former makes disposition of property for the sake of public utility, while the latter does so for private uses, and also in that the former power is wielded by the Ruler of the State, the later by the private individual who owns the property."

He further says that sovereignty (imperium) contains eminent domain as a part, but that the later is separable from sovereignty, and might be reserved or limited by the people, and he attributes to sovereignty (si salus publica exigat) the right to dispose of the persons of the citizens. This power, which he calls "Potestas Eminens," is also contained in sovereignty.

The two powers, dominium eminens and potestas eminens, he combines in "jus eminens imperantis"-the eminent right over the goods and persons of the citizens or subjects. This right proceeds from necessity. Its measure is salus publica.

According to his argument the members of the State tacitly consent to dominium eminens and potestas eminens, and he also asserts that, when private property is taken by eminent domain there should be to the extent possible, a satisfaction by the public, that the damage may be borne pro rata.

In Vattel's Law of Nations, printed at Neufchatel, in I773, we read in Book I, Chap. XX, p. II2:

"Everything in political society ought to tend to the good of the community; and, since even the persons of the citizens are subject to this rule, their property cannot be excepted. The

${ }^{6}$ Si salus publica exiget, ut Rector civitatis certo modo disponat de rebus civium; jus ita dispondi eidem competit.

7 Differt dominium a domnio communi, quod illo disponatur de rebus utilitatis publicae, hoc autem utilitatis privatorum causa et quod illo utatur qui civitatem regit, hoc autem privatus, cujus res sunt. 
State could not subsist, or constantly administer the public affairs in the most advantageous manner, if it had not a power to dispose occasionally of all kinds of property subject to its authority. It is even to be presumed that, when the nation takes possession of a country, the property of certain things is given up to the individuals only with this reserve. The right which belongs to society, or to the sovereign, of disposing, in case of necessity, and for the public safety, of all the wealth contained in the State, is called the Eminent Domain. It is evident that this right is, in certain cases, necessary to him who governs, and consequently is a part of the empire, or sovereign power, and ought to be placed in the number of the prerogatives of majesty. When, therefore, the people confer the empire on any one, they at the same time invest him with the Eminent Domain, unless it be expressly reserved. Every prince, who is truly sovereign, is invested with this right when the nation has not excepted it, however limited his authority may be in other respects.

"If the sovereign disposes of the public property in virtue of his eminent domain, the alienation is valid, as having been made with sufficient powers.

"When, in a case of necessity, he disposes in like manner of the possessions of a community, or an individual, the alienation will, for the same reason, be valid. But justice requires that this' community, or this individual, be indemnified at the public charge ; and if the treasury is not able to bear the expense, all citizens are obliged to contribute to it; for, the burden of the State ought to be supported equally or in a just proportion. The same rules are applicable to this case as to the loss of merchandise thrown overboard to save the vessel."

\section{ITS LEGAL FORMATION.}

The legal formulation of Dominium Eminens in the law of Continental Europe, may be said to date from the year 1802, when it first appears in definite terms in the Code Napoleon; but in spite of the declarations of principle therein contained, Napoleon continued to use confiscation as a military weapon against internal enemies, and this right of spoliation was withdrawn only by the "Charte de I814." In the Civil Code the "Public Necessity" of the Declaration of Rights in 1789 , became "Public Utility" in Art. 545 of the Code, which reads: 
"No one can be constrained to yield up his property, unless it be for the cause of 'Public Utility' and in consideration of a just and previous indemnity." 8

This declaration of "Public Utility" was at first construed as being satisfied by a mere order of the prefecture, but in the celebrated "Note de Schoenbrumn," Napoleon decreed that it should emanate from the Chief of the State, and as a general principle, the work to be undertaken by the State, is declared to be of public utility by an act of the legislative power, voted as a law,

Bosquet, in his "Explication du Code Civil,' Avignon, 1805, comments on Art. 545 as follows:

"To the citizen belongs the ownership (propriété) and to the sovereign sovereignty (empire). This is from Seneca, Book VII, Chap. 5 and 5 de beneficiis; 'Omnia rex imperio possidet, singuli dominio." Such is the maxim of every country, and of every epoch."

Basquet cites Wolff, Jus Naturae, $\$ 103$, to the effect that (l'empire) sovereignty does not embrace the idea of ownership. "Imperium non includit dominium feodorum vel rerum quarumque civium."10 It consists solely in the power of governing. It is only the right to prescribe and order what is necessary for the public good, and consequently to direct things and persons. It gives to the State only the right to regulate the use of these goods by civil laws, the power to dispose of them for objects of public utility, and the factulty of raising taxes on the same goods. These different rights combined, form what Grotius, Pufendorf and others call Eminent Domain. Words whose real sense supposes no right of property, and whose real sense is relative only to the inseparable prerogative of public power. Basquet mentions the solemn discussion in all the universities of Europe on the inaccuracy of the term, and also the dissertation of Leyser Wirtemburg, I673, "Pro imperio contra dominium eminens," and goes on to say that, for the State to exist, it must have the means to provide for the expense of government. In this the sovereign does not exercise a right of

8 "Nul ne peut être constraint de cédar sa proprieté si ce n'est pour cause d'utilité publique, et moyennant une juste et préalable indemnité."

9 The king possesses all things through his sovereignty, the individual citizens (possess them) by their rights of ownership.

10 "The sovereign power does not include dominion over vassals or the property of individual citizens." 
property, but simply a power of administration. It is not as a paramount and universal owner of land, but as supreme administrator of the public interest, that the sovereignty makes civil laws to regulate the use of private property. When the legislator promulgates regulations of private property, he intervenes, not as a master, but merely as the arbitrator, and as the regulator for the maintenance of good order and peace, and, according to Basquet, serious motives of public utility alone should suffice for the exercise of eminent domain, without a rigorous and absolute necessity being required. Domat is also emphatic on the point that there should be indemnity in all cases, and approvingly cites Baldus where he says, "It is an atrocious power that would utake the property of another without compensation."11

He also discusses the arrogation of utilities in private properties, still effective in a large part of Europe, though happily proscribed in France. He mentions the rules of the feudal system which show that there were some glimmerings of reason, which revealed the sacred truths that ought to dominate social order. In the countries most thoroughly feudal, certain free and allodial lands were recognized, which fact proves that feudal seignory was never considered as a necessary consequence of sovereignty.

\section{THE APPLICATION OF THE POWER TO-DAY IN CONTINENTAL EUROPE. \\ FRANCE.}

The judicial authority of France has had the right to fix indemnities since the year of I81o, and the "Tribunal Civil" renders a "jugement d'expropriation" in cases where the owner does not consent to a "cession aimable," but works of slight importance, such as railways and canals less than twenty kilometres in length may be authorized by a decree of the Conseil d'Etat; while public works at the cost of departments and communes, may be authorized by "simple decree," and the making of local and rural roads, by the Conseil General, or by the Department Commission.

Article 545 of the Code Napoleon says that the indemnity must be "préalable." However, the expropriation is pronounced by the tribunal before the indemnity is paid, or even fixed, but the principle of the Declaration of Rights is saved by not requiring possession until after the payment of the indemnity. (Law of

11 Diabolica potestas est, auffere rem alienam, sine praetio. 
May 3rd, I84I, Art. 53.) The owner has the right of retention to assure his payments; Planiol, "Traité Elémentaire de Droit Civil," Paris, I904, Vol. I, Chap. IV.

Under the Law of May 3, I84I, there must be,

(a) A declaration of public utility, made by the legislative power, for the great works undertaken by the nation, and by the executive power, for works undertaken by provinces and communes.

(b) The locality must be designated, together with the individual properties which it is proposed to occupy; this is done either in the same decree that declares the public utility, or in a decree of the prefecture. The individual properties are designated in a decree of the prefecture, plans are deposited in the municipal offices, and publication is made.

(c) Expropriation, when not a voluntary cession, is the effect of the judgment of the civil tribunal where the property is situated. At this point the administrative procedure becomes judicial. This sentence of expropriation cannot be pronounced unless all the administrative formalities have been complied with. There is a jury, and the judgment is not appealable. It can go to the Court of Cessation only for excess of power, or invalidity, or defect of form. Nevertheless, the former owner retains the right to possession, and all fruits thereof, until he is duly paid.

(d) Fixing the indemnity is entrusted to a special jury, which was provided for in $1833 ;$ this is composed of twelve jurors, drawn from the property owners and tax-payers, presided by a judge delegated by the Tribunal. The cause is heard on proper evidence, and indemnity, not less than that offered by the expropriator, nor more than that asked by the expropriated owner, is allowed. It must always be a fixed sum. This becomes executory on order of the presiding judge, and the next step is,

(e) The payment of the indemnity into the hands of those entitled. If it is refused, it is paid over to a public depository, and possession is taken in favor of the expropriator.

( $f$ ) The last stage concerns cases of retrocession, where the project is abandoned, or the land is not used. Litigation of this character is in the general jurisdiction of the courts. In certain jurisdictions, expropriation is looked upon as a piece of good fortune, and in Corsica the indemnities are so excessive that the exectution of public works is practically impossible. 


\section{. GERMANY.}

The Prussian Law of June II, I874, is still in force, and prescribes complete indemnity (Art. I) in the case of expropriation for public utility. There must be a royal decree which designates the enterprise and the work on account of which expropriation is made. For the rectification and widening of public roads, the expropriation is declared by local authority (Art. 3-4). The indemnity is payable in money, but there are cases covered by special laws where it may be in land.

The indemnity equals the whole value of the land taken, including accessories and fruits (revenues). Where the expropriation is partial the indemnity embraces the greater value of the part taken by reason of its material or economic union with the whole and the lesser value of the part not taken by reason of the expropriation of the other part (Art. 8).

The expropriated owner may renounce, with compensation, the remaining part not readily usable. It should be possible for the owner to procure with the indemnity other land yielding the same revenue or equally usable. But not if account is taken of the benefits from the new works.

A special indemnity is due persons having special interests, usuffructuaries, owners of servitudes, lessees, etc., when damages to these are not included in the owner's indemnity. The indemnity should be paid to the person in favor of whom it is fixed, and when not paid or deposited, draws five per cent interest from the date of expropriation until payment or deposit (Art. 36).

There is a provision not found in other laws that where it is impossible to fix the indemnity in advance, the proprietor may have security.

The law introducing the German Code of Civil Procedure (Civilprozeszordnung) leaves untouched the provisions of the "Landesgesetz" on the procedure in litigation relating to expropriation (Zwangsenteignung) and indemnity (Bk. III, Sec. I4).

\section{SPAIN.}

In Spain the idea (Enajenacion forzosa) seems to have crystalized comparatively early. Eschrishe. Dict. de legisl. y Jurispr., p. 6rg, defines it as "the cession or sale which a person or corporation is required to make of a private thing for reasons of public utility." He says: "It is a general principle consecrated 
by our laws, ancient and modern, that no one can be deprived of his property except on account of the common utility and with a corresponding indemnity. Ley. 3 , tit. I, part 2 ; ley 3 I, tit. I8, part 3 , and Art. Io of the Const. of I837. The procedure was fixed by the statute of July 14,1836 .

\section{BELGIUM.}

The law of April 17,1835 , provides a mixed system intended to reconcile the needs of public law with the constitutional principle of previous indemnity.

Possession can be taken only after payment of deposit of the indemnity fixed by the Court of first instance. The law of May 27 , I870, simplifies the administrative procedure and repeated all remaining provisions of the French law of 1810 .

\section{AUSTRIA.}

Has no general law on expropriation for public utility. There are found many scattered provisions, and also in the Railways Law of Feb. I8, I878. In the case of railways the declaration of public utility emanates from the executive power. Indemnity is fixed by the district tribunal, composed of a single judge. It reaches lands, water rights, servitudes and other real rights and every necessary limitation of private property.

Usufructuaries, lessees, etc., are compensated by the expropriated owner. Indemnity is a lump sum for permanent occupation and a rental for temporary occupation.

\section{RUSSIA.}

The Civil Code, Articles 575, 608, contain dispositions relative to temporary and permanent expropriation.

\section{HUNGARY.}

'The law of May 3I, I8II, is still in force. Its provisions are quite different from those of laws in other countries, and hence, it is not a type. The same is true of the backward countries of Europe.

\section{ITALY.}

The Italian legislation is said (Digesto Italiana) to comply with the following scientific principles: 
(a) There should be no expropriation without the expression of the will of the State; i. e., without a law.

(b) There should be no expropriation without ascertaining the necessity, or at least the utility of proceeding in the public interest.

(c) No expropriation should take place without previous payment of a just indemnity; $i$. e., without complete and effective compensation in money for the property taken.

(d) The fixing of the indemnity should be had upon stable and safe criteria, and by administrative proceeding, supplemented when necessary by an ordinary judicial proceeding.

(e) There should be no indemnity when the value of the land taken cannot be fixed in money.

$(f)$ There should be no undertaking to restore the property expropriated to the former owner when it no longer answers the public purpose for which taken.

The indemnity is fixed by the "'Autorita gindiziaria,' natural protectress of the rights of citizens and of society. It is competent to weigh with equal scales the interests of the administration and private rights." There seems to be no special jury. The indemnity must be paid or deposited in a public depository. Certain urgent cases are specially provided for by law.

In Italy, with its great variety of monuments and public works, the legislation is most complete and scientific. The subject is controlled by the (fundamental) law of June 25, I865, No. 2359, partially modified by the laws of Dec. 18 , I879, and Jan. I5, I885, and some special laws.

Thus we see that the emergence of the power of Eminent Domain was held back by the collective institutions of Roman law, and appeared first with the origin of individual ownership of property, and the respect for the rights of the citizen, which was one of the most important features of Roman law. It was again retarded by the military system of mediæval times, when the attribute of the state as a source of legislation was lost, and law became a local institution. I't became gradually stronger with the evolution of civil society, and received its speculative formulation by those natural law philosophers who disputed keenly and learnedly on the qualities of the power, and so, when it received its legal formulation in the Code Napoleon, ample authority for it was found in the works of the scientific law writers of the preceding centuries. 
The principle has made rapid progress in America, where the growth of cities and railroads, and the general demand for public works, is unprecedented, but its interpretation and application. varies in the different states, and a careful study of the continental. law of Eminent Domain, as it is now applied in those countries, may be found not only most interesting, but also of great instructive value, to the student of law.

I4I Broadway, New York City.

William D. McNulty. 